\title{
KUALITAS PELAYANAN DAN KEPUASAN MAHASISWA SEBAGAI ANTESEDEN VALENSI WORD OF MOUTH PADA MAHASISWA UNIVERSITAS MUHAMMADIYAH MALANG
}

\author{
H. B. Ardianto*) \\ Nazaruddin Malik $^{* *}$ dan Eko Handayanto ${ }^{* *}$ \\ Magister Manajemen Universitas Muhammadiyah Malang \\ E-mail:Hbardianto@yahoo.co.id
}

\begin{abstract}
A research to examined the effect service quality toward student satisfaction, effect of service quality toward word of mouth valence, effect of student satisfaction toward word of mouth valence of student University of Muhammadiyah Malang. The treatment were used questionnaire, each statement on questionnaire used to know respondent respon very disagree until very agree. Based on answer questionnaire result collected 105 responden, data were analysis technique of Structural Equation Model (SEM). The result show that service quality has a positive influence and significant toward student satisfaction, service quality has a positive influence but not significant toward word of mouth valence, student satisfaction has a positive influence and significant toward word of mouth valence. Data result show that service quality has an indirect positive influence toward word of mouth valence through student satisfaction. Student satisfaction has a direct positive influence and significant toward word of mouth valence on private university.
\end{abstract}

Key words: service quality, satisfaction, word of mouth valence

\section{PENDAHULUAN}

Valensi word of mouth merupakan derajat penilaian (positif atau negatif) diberikan seseorang yang melakukan aktivitas word of mouth (Davidow, 2003). Pada sektor jasa, valensi word of mouth terjadi ketika konsumen mulai membicarakan pengalaman pelayanan yang diberikan oleh penyedia jasa. Hal - hal mengenai variabel yang menentukan terjadinya valensi word of mouth menarik untuk diidentifikasi dalam suatu penelitian.

Anteseden valensi word of mouthmerupakan serangkaian variabel awal pada terjadinya valensi word of mouth. Kualitas pelayanan dan kepuasan merupakan variabel yang mempengaruhi terjadinya word of mouth (Matos and Rossi, 2008). Konsumen yang telah melakukan transaksi konsumsi terhadap suatu jasa dapat merasakan dinamika kualitas pelayanan yang disediakan oleh penyedia jasa, sehingga mempengaruhi kepuasan yang selanjutnya akan terjadi valensi word of mouth (Khraim, 2011; Ekiz et al., 2008). Selama perkembangan ilmu mengenai word of mouth, ada beberapa penelitian berdasarkan klasifikasi jasa tertentu yang menjelaskan bahwa kualitas pelayanan berpengaruh signifikan terhadap word of mouth (Matos and Rossi, 2008; Sa' adah, 2011; Sudiasa, 2011). Sedangkan ada beberapa penelitian yang menjelaskan bahwa word of mouth dapat terjadi dari variabel kualitas pelayanan penyedia jasa setelah melalui kepuasan konsumen terlebih dahulu (Wijaya, 2008; Wantara, 2009; Sudiasa, 2011).

Perguruan tinggi swasta merupakan satuan pendidikan yang menyelenggarakan pendidikan tinggi dikelola secara mandiri oleh suatu yayasan. Indrajit dan Djokopranoto (2004) menyatakan bahwa perguruan tinggi swasta memiliki kesamaan 
dengan perusahaan dalam suatu dimensi korporasi. Jumlah perguruan tinggi yang tercatat di lingkungan Ditjen Pendidikan Tinggi sampai dengan tahun 2008 sebanyak 3.016, terdiri atas 83 Perguruan Tinggi Negeri (PTN) dan 2.933 Perguruan Tinggi Swasta (PTS) (Sailah, 2009). Data menjelaskan bahwa perguruan tinggi swasta lebih banyak dibandingkan dengan perguruan tinggi negeri, sehingga memberikan peluang bisnis untuk melakukan rekrutmen calon mahasiswa dan mempertahankan mahasiswa yang telah menentukan pilihan melanjutkan pendidikan di perguruan tinggi swasta. Dinamika pemasaran pendidikan tinggi diharapkan tidak menggunakan promosi penjualan untuk menarik minat konsumsi mahasiswa. Konsumen (mahasiswa) dapat menggunakan valensi word of mouth sebagai referensi lisan yang dapat diperoleh dalam menentukan pilihan konsumsi.

Analisis anteseden valensi word of mouth pada perguruan tinggi swasta dalam penelitian ditinjau dari variabel kualitas pelayanan dan kepuasan mahasiswa. Penelitian Hanaysha et al. (2011) menjelaskan tentang kualitas pelayanan universitas berpengaruh positif dan signifikan terhadap kepuasan mahasiswa. Sedangkan Khraim (2011) dan Teerawut (2011) memberikan wawasan bahwa kepuasan mahasiswa merupakan faktor - faktor yang berkontribusi mempengaruhi valensi word of mouth. Adapun tujuan penelitian terdiri dari (a) Menguji pengaruh kualitas pelayanan terhadap kepuasan mahasiswa, (b) Menguji pengaruh kualitas pelayanan terhadap valensi word of mouth, (c) Menguji pengaruh kepuasan mahasiswa terhadap valensi word of mouth.

\section{TINJAUAN PUSTAKA}

Hasil penelitian Matos and Rossi (2008) menjelaskan bahwa word of mouth dapat dipengaruhi oleh kualitas (kualitas pelayanan), kepuasan, loyalitas, komitmen, kepercayaan, dan persepsi nilai. Tinjauan penelitiannya menjelaskan bahwa variabel kualitas pelayanan dan kepuasan ternyata berpengaruh positif terhadap terciptanya aktivitas word of mouth. Sedangkan kepuasan dan loyalitas berpengaruh positif terhadap terjadinya aktivitas word of mouth melalui valensi word of mouth.

Hasil penelitian Khraim (2011) menjelaskan bahwa satisfaction, experience, incentives, dan source berpengaruh terhadap terjadinya word of mouth. Variabel satisfaction, experience, incentives, dan sourcememberikan pengaruh signifikan pada komunikasi word of mouth. Valensi berupa positif word of mouth disebarkan oleh mahasiswa sehingga membantu proses pemasaran di Universitas. Universitas dapat menggunakan komunikasi word of mouth yang dilakukan oleh mahasiswa sebagai alat pemasaran yang potensial.

Hasil penelitian Hanaysha et al. (2011) menjelaskan bahwa dimensi kualitas pelayanan yang terdiri dari tangibility, reliability, responsiveness, assurance, dan empathy berkorelasi positif terhadap kepuasan mahasiswa. Selain itu, diketahui bahwa secara umum ada indikasi mayoritas mahasiswa merasa puas dengan fasilitas yang disediakan oleh universitas.

Jasa dapat didefinisikan melalui beberapa pendekatan - pendekatan oleh para ahli ilmu pengetahuan dalam suatu fenomena yang terjadi di masyarakat. Jasa merupakan pelayanan yang diberikan oleh manusia melalui suatu hal yang dapat dilihat (explicit service) maupun yang tidak dapat dilihat, bisa dirasakan (implicit service) sampai kepada fasilitas - fasilitas pendukung yang harus tersedia dalam penjualan jasa (Jasfar, 2005). Definisi jasa menurut Alex (2006) merupakan suatu produk tidak berwujud yang melibatkan suatu perbuatan, kinerja, atau usaha yang secara fisik tidak dapat dimiliki. Sedangkan Kotler dan Keller (2006) mengemukakan pengertian jasa merupakan setiap tindakan atau kegiatan yang dapat ditawarkan oleh satu pihak kepada pihak lain, yang pada dasarnya tidak berwujud dan tidak mengakibatkan kepemilikan apapun.

Tjiptono et al (2008) dan Adisaputro (2010) mendefinisikan jasa ialah setiap perbuatan atau kinerja yang dapat ditawarkan suatu pihak kepada pihak lain yang pada dasarnya bersifat tidak tampak (intangible) dan tidak mengakibatkan adanya perpindahan kepemilikan atas sesuatu. Adisaputro (2010) menjelaskan karakteristik jasa yang berbeda dengan barang terdiri dari aspek ketidaktam- 
pakan (Intangibility), aspek ketidakterpisahan (Inseparability), kesulitan penyeragaman produk jasa (Variability), dan ketidakmungkinan disimpan (Perishability).

Pengelompokkan jasa akan membantu peneliti dalam memahami manajemen jasa. Berdasarkan Gambar 1, jasa dapat diklasifikasikan menjadi empat kategori yaitu pabrik jasa, toko jasa, jasa massal, jasa profesi.

\begin{tabular}{|c|c|c|}
\hline & \multicolumn{2}{|c|}{ Degree of Interaction and Customization } \\
\hline & Low & High \\
\hline Degree & $\begin{array}{l}\text { Service Factory } \\
\text { - Airlines } \\
\text { - Trucking } \\
\text { - Hotels }\end{array}$ & $\begin{array}{l}\text { Service Shop } \\
\text { - Hospitals } \\
\text { - Auto repair } \\
\text { - Other repair services }\end{array}$ \\
\hline $\begin{array}{l}\text { of Labor } \\
\text { Intensity }\end{array}$ & $\begin{aligned} & \text { Mass Service } \\
& \text { - Retaling } \\
& \text { - Wholesaling } \\
& \text { - Schools } \\
& \text { - Retail aspects of } \\
& \text { commercial banking }\end{aligned}$ & $\begin{array}{l}\text { Professional Service } \\
\text { - Doctors } \\
\text { - Lawyers } \\
\text { - Accountants } \\
\text { - Architects }\end{array}$ \\
\hline
\end{tabular}

Gambar 1. Tabel proses jasa (Schmenner, 1986)

Perguruan tinggi memberikan jasa kepada masyarakat berupa pendidikan tinggi dalam bentuk proses belajar mengajar dan penelitian mengenai ilmu pengetahuan. Indrajit dan Djokopranoto (2004) berpendapat bahwa bisnis yang dilakukan oleh perguruan tinggi selama ini yaitu ilmu pengetahuan. Alma (2008) mendefinisikan pemasaran jasa pendidikan merupakan kegiatan lembaga pendidikan memberi layanan atau menyampaikan jasa pendidikan kepada mahasiswa dengan cara yang memuaskan. Berdasarkan penjelasan tersebut diketahui bahwa pemasaran jasa pendidikan selalu memperhatikan kepuasan pelanggan.

Bowen dalam Sawaji et al. (2010) menjelaskan bahwa produk perguruan tinggi yaitu pembelajaran (instruction), penelitian (research), dan pengabdian masyarakat (public services). Produk utama (the chief product) dari perguruan tinggi yaitu pembelajaran (teaching learning), sedangkan produk sampingannya (by-product) berupa personal self discovery, career choice and placement, dan direct satisfactions and enjoyments. Dill dalam Sawaji et al. (2010) menuliskan bahwa perguruan tinggi dapat dipandang sebagai bagian dari industri ekonomi yang menyediakan derajat akademik, penelitian, dan pengabdian.

Menurut Parasuraman et al. (1988) dapat disimpulkan bahwa terdapat lima dimensi kualitas jasa yang terdiri dari bukti fisik (tangibles), reliabilitas (reliability), daya tanggap (responsiveness), jaminan (assurance), empati (empathy). Storey dan Easingwood (1998) berpendapat bahwa manajemen harus memahami keseluruhan layanan yang ditawarkan dari sudut pandang pelanggan. Barata (2006) berpendapat bahwa ukuran kualitas pelayanan bukan hanya ditentukan oleh pihak yang melayani saja tetapi lebih banyak ditentukan oleh pihak yang dilayani (konsumen), sehingga dapat mengukur kualitas pelayanan berdasarkan harapan konsumen dalam memenuhi kepuasannya.

Kepuasan merupakan perasaan senang atau kecewa seseorang yang muncul setelah membandingkan antara kinerja produk atau jasa yang diterima terhadap kinerja produk yang diharapkan (Kotler et al., 2006). Suatu kinerja yang berada di bawah harapan akan membuat konsumen tidak puas. Suatu kinerja yang memenuhi harapan akan membuat konsumen puas. Pelanggan yang puas cenderung tetap loyal lebih lama, membeli lebih banyak, kurang peka terhadap perubahan harga dan melakukan pembicaraan yang menguntungkan perusahaan. Harjadi dan Fatmasari (2008) berpendapat bahwa jika seorang konsumen merasa puas, maka konsumen akan bicara pada satu orang saja, dan jika konsumen tidak puas akan bicara kepada sepuluh orang. Dengan demikian akan terjadi suatu word of mouth dari kepuasan konsumen.

Word of mouth merupakan komunikasi interpersonal antara dua atau lebih dari individu konsumen tentang barang dan jasa (Anonymous, 2007; Williams, 2007; Alexandru, 2010). Word of mouth tidak dapat diciptakan sehingga tidak berusaha untuk membohongi konsumen. Konsumen yang terpengaruh oleh word of mouth dapat mendorong kegiatan pembelian produk atau jasa, mempengaruhi komunitas, serta efisien bagi kegiatan pemasaran suatu perusahaan karena tidak memerlukan biaya yang besar (low cost). Word of mouth merupakan satu faktor penting yang berpengaruh terha- 
dap keputusan seseorang dalam membeli suatu produk atau jasa (Gremier et al.,1997; Bates, 2005; Harjadi dan Fatmasari, 2008).

Tinjauan penelitian Matos and Rossi (2008) menyatakan bahwa word of mouth positif dan word of mouth negatif merupakan bentuk valensi. Valensi (valence) word of mouthmengilustrasikan seseorang yang terlibat dalam aktivitas word of mouth dengan penilaian berupa positif atau negatif, dimana pelanggan mempunyai suatu keyakinan terhadap word of mouth yang diterima maupun yang disampaikan kepada orang lain. Williams (2007) mengilustrasikan bahwa positif dan negatif word of mouth merupakan valensi word of mouth terhadap stimuli dan selanjutnya terjadi rekomendasi seseorang dalam aktivitas word of mouth. Valensi (valence) mengacu pada atribut - atribut yang mempengaruhi keyakinan pelanggan bahwa hasil suatu jasa itu baik atau buruk, terlepas dari evaluasi pelanggan terhadap aspek lain tentang pengalamannya dalam dimensi utama kualitas jasa (Brady dan Cronin, 2001). Valensi word of mouth yang terjadi dapat memunculkan aktivitas word of mouth (Matos and Rossi, 2008).

Word of mouth valence dapat bersifat positif atau negatif. Word of mouth valence positive didukung oleh adanya kepuasan yang dirasakan oleh pelanggan, karena kepuasan merupakan cerminan dimana perusahaan dapat mengatasi keluhan pelanggan. Keluhan merupakan sebuah pertanda adanya ketidakpuasan. Apabila keluhan pelanggan tidak ditindaklanjuti, pelanggan akan pindah ke pemasok dan/atau merek produk atau jasa yang lain, berpartisipasi dalam word of mouth (WOM) negatif, atau melakukan keluhan ke organisasi/pihak ketiga (Davidow, 2003, Ekiz et al., 2008).

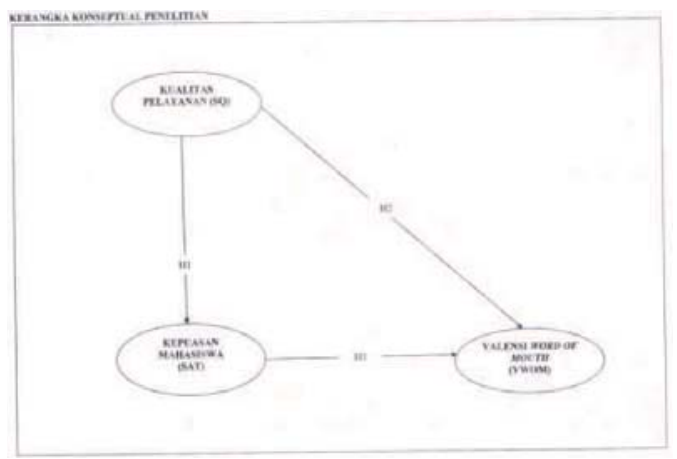

Gambar 2 2.Rerangka konseptual penelitian
Berdasarkan rumusan masalah dan tinjauan pustaka yang dikembangkan dalam penelitian ini, maka sebuah model untuk penelitian ini dapat dikembangkan seperti pada Gambar 2.3.

Keterangan sumber referensi rerangka konseptual penelitian:

H1: Sylvana (2006), Natalisa (2007), Hanaysha (2011), Hanaysha et al. (2011), Sukwadi et al. (2011)

H2: Matos and Rossi (2008), Sa'adah (2011), Sudiasa (2011)

H3: Matos and Rossi (2008), Ekiz et al. (2008), Khraim (2011)

Kualitas pelayanan diidentifikasi mempengaruhi kepuasan pelanggan (Khodayari and Khodayari, 2011; Marimuthu and Ismail, 2012). Hanaysha et al. (2011) melakukan penelitian yang menjelaskan bahwa tangibility, reliability, responsiveness, assurance, and empathy berpengaruh positif dan signifikan terhadap kepuasan mahasiswa. Sedangkan Ahmed et al. (2010) melakukan penelitian yang menghasilkan bahwa bukti fisik (tangibles), daya tanggap (responsiveness), dan empati (empathy) berpengaruh positif terhadap kepuasan mahasiswa. Asumsi yang terjadi pada kualitas pelayanan berpengaruh positif pada kepuasan mahasiswa diperkuat oleh hasil penelitian Sylvana (2006), Natalisa (2007), Hanaysha (2011), Sukwadi et al. (2011). Hipotesis yang diajukan mengenai hubungan kualitas pelayanan dengan kepuasan mahasiswa sebagai berikut:

H1: Kualitas pelayanan berpengaruh positif terhadap kepuasan mahasiswa

Kualitas pelayanan diasumsikan mempengaruhi valensi word of mouth (Walker, 2001; Bruce and Edgington, 2008). Matos and Rossi (2008) menjelaskan bahwa kualitas pelayanan berpengaruh positif terhadap valensi word of mouth terdiri dari word of mouth positif, word of mouth campuran, dan word of mouth negatif. Penelitian Sa'adah (2011) menghasilkan bahwa kualitas pelayanan berpengaruh positif dan signifikan pada word of mouth yang terjadi sesuai dengan yang dirasakan oleh konsumen di suatu restoran. Sudiasa 
(2011) melakukan penelitian yang menghasilkan bahwa kualitas pelayanan berpengaruh positif dan signifikan terhadap word of mouth. Namun, selanjutnya kualitas pelayanan bepengaruh positif dan signifikan secara tidak langsung terhadap word of mouth melalui kepuasan pelanggan (Sudiasa, 2011). Abiawan (2011) melakukan studi lapang yang menghasilkan bahwa kualitas pelayanan berpengaruh signifikan namun lemah terhadap word of mouth. Hipotesis yang diajukan mengenai hubungan kualitas pelayanan dengan valensi word of mouth sebagai berikut:

H2: Kualitas pelayanan berpengaruh positif terhadap valensi word of mouth

Kepuasan pelanggan akan berhubungan dengan valensi word of mouth. Matos and Rossi (2008) melakukan tinjauan ilmiah bahwa kepuasan pelanggan berpengaruh positif terhadap valensi word of mouth. Kepuasan mahasiswa berpengaruh positif pada valensi word of mouth diperkuat oleh hasil penelitian Ekiz et al. (2008), Khraim (2011). Hipotesis yang diajukan mengenai hubungan kepuasan mahasiswa dengan valensi word of mouth sebagai berikut:

H3: Kepuasan mahasiswa berpengaruh positif terhadap valensi word of mouth

\section{METODE PENELITIAN}

Objek yang digunakan dalam penelitian ialah Universitas Muhammadiyah Malang. Dalam penelitian digunakan dua jenis data, yaitu data primer dan data sekunder. Pada penelitian ini, sumber data primer diperoleh langsung dari kuesioner yang telah dijawab oleh mahasiswa Universitas Muhammadiyah Malang. Data sekunder merupakan sumber data penelitian yang diperoleh peneliti secara tidak langsung melalui media perantara (literatur literatur, jurnal - jurnal penelitian, data dokumen lainnya). Metode penelitian yang digunakan untuk data primer merupakan metode kuantitatif. Pemilihan jenis metode ini berdasarkan upaya mengetahui hubungan antara kualitas pelayanan, kepuasan mahasiswa, dan valensi word of mouth di Universitas Muhammadiyah Malang.
Penentuan populasi pada penelitian ini adalah mahasiswa Universitas Muhammadiyah Malang. Sementara unit analisis penelitian adalah mahasiswa yang terdaftar aktif melakukan kegiatan pendidikan di Universitas Muhammadiyah Malang. Penentuan unit analisis penelitian didasarkan pada suatu asumsi peneliti bahwa mahasiswa yang terdaftar aktif mengikuti perkuliahan di Universitas Muhammadiyah Malang mempunyai pengalaman dan pengamatan yang cukup tentang kualitas pelayanan yang ada di Universitas Muhammadiyah Malang.

Penelitian ini menggunakan metode pemilihan sampel secara non probability sampling method dengan pertimbangan bahwa kriteria populasi tidak memiliki kesempatan atau peluangyang sama untuk dipilih menjadi sampel. Sampel yang digunakan dalam penelitian ini terdiri dari sejumlah tertentu mahasiswa Universitas Muhammadiyah Malang dari populasi yang ada. Sampel diambil dengan cara mendatangi responden ke Universitas Muhammadiyah Malang. Pada penelitian ini terdapat 21 indikator, sehingga jumlah sampel yang diperlukan adalah 21 x $5=105$ sampel. Penelitian dilaksanakan di Universitas Muhammadiyah Malang, sejak Februari 2012 hingga April 2012.

Penelitian menggunakan sampel aksidental (accidental sampling). Accidental samplingyaitu teknik sampling dilakukan dengan mengambil orang - orang yang dipilih secara kebetulan (spontanitas). Menurut Asnawi dan Masyhuri (2009) sampling aksidental menggunakan anggota populasi yang secara kebetulan dijumpai pada saat penelitian sesuai dengan ciri - ciri yang telah ditentukan oleh peneliti. Peneliti menggunakan sampel aksidental (accidental sampling) karena menggunakan mahasiswa dengan ciri - ciri tertentu untuk menjadi sampel. Adapun ciri tersebut adalah mahasiswa yang minimal sudah berada pada semester empat pada saat penelitian dilakukan.

Metode pengumpulan data yang digunakan adalah single cross-sectional design. Pengumpulan data dilakukan sendiri oleh peneliti dengan alat penelitian berupa kuesioner. Metode pengumpulan data menggunakan kuesioner untuk memperoleh data primer dilakukan dengan cara personally administered questionnaire, dimana responden 
diminta untuk mengisi langsung kuesioner yang dibagikan di tempat dan tidak dibawa pergi. Kuesioner dibagikan kepada mahasiswa Universitas Muhammadiyah Malang yang sudah menyatakan kesediaannya untuk menjadi responden. Responden menjawab kuesioner di tempat dan kemudian mengembalikannya kepada peneliti. Pengumpulan data dilakukan hingga terkumpul jumlah data yang mencukupi untuk dianalisis. Pengumpulan data dilakukan dengan menggunakan dua macam angket, yaitu angket terbuka (data pribadi responden seperti jenis kelamin, fakultas, dan sebagainya) dan angket tertutup (mengukur indikator - indikator pada penelitian ini dengan memberikan pilihan jawaban kepada responden yang sudah tersedia dengan skala 1 sampai dengan 5).

Berdasarkan hipotesis yang diajukan dalam penelitian ini maka teknik analisis data yang digunakan adalah sebagai berikut: 1) Uji validitas dan reliabilitas data. Validitas diuji dari confirmatory factor analysis (CFA), dimana setiap indikator dengan standardized regression weights atau loading factoryang tersedia pada analisis tersebut $<0,50$ dapat dikeluarkan dari skala konstruk, sementara indikator penelitian yang memiliki loading factor $\geq 0,50$ akan dipertahankan sebagai asumsi bahwa indikator penelitian dapat dikatakan telah valid. Sedangkan reliabilitas data diuji dari hasil Cronbach Alpha (CA) yang diharapkan setiap konstruk memiliki nilai cut-off $>0,70$ sebagai asumsi bahwa konstruk dapat dikatakan reliabel. 2) Uji validitas dan reliabilitas konstruk. Di dalam Structural Equation Model (SEM), reliabilitas instrumen keseluruhan indikator dapat diperiksa menggunakan construct reliability dan variance exrtacted. Suatu instrumen dikatakan reliabel bilamana $\pi_{\eta} \geq 0,70$ untuk loading factor $\left(\lambda=\right.$ Lamda). Nilai variance exrtacted $\left(\pi_{\mathrm{vc}(\eta)}\right)$ menunjukkan proporsi varian variabel laten yang dapat dijelaskan oleh indikator variabel, bilamana $\pi_{\mathrm{vc}(\eta)}>0,50$, maka validitas indikator secara individu dapat dipertimbangkan. 3) Asumsi pada Structural Equation Model (SEM). Asumsi pada Structural Equation Model (SEM) terdiri dari ukuransampel, normalitas, Outliers, Multicollinearity dan Singularity. 4) Analisis data kuantitatif. Alat analisis yang digunakan dalam mengolah data untuk menguji hipotesis yang diajukan dengan menggunakan Structural Equation Model(SEM). Penelitian menggunakan LISREL (Liniear Structural REL ationships) sebagai program statistik untuk Structural Equation Model (SEM). Dengan menggunakan LISREL, peneliti dapat menganalisis struktur kovarian yang rumit. Variabel laten, saling ketergantungan antar variabel, serta sebab akibat yang timbal balik dapat diestimasi dengan menggunakan model pengukuran dan persamaan yang terstruktur.

Suatu pemodelan SEM yang lengkap pada dasarnya terdiri dari measurement model dan structural model. Measurement model atau model pengukuran ditujukan untuk mengkonfirmasi sebuah dimensi atau faktor berdasarkan indikator - indikator empirisnya. Beberapa langkah yang perlu dilakukan dalam membuat pemodelan yang lengkap terdiri dari pengembangan model teoritis, pengembangan diagram alur untuk menunjukkan hubungan kausalitas, konversi diagram alur ke dalam serangkaian persamaan struktural dan spesifikasi model pengukuran, pemilihan matriks input dan teknik estimasi atas model yang dibangun, menilai problem identifikasi, evaluasi model, Interpretasi dan modifikasi model.

\section{HASIL PENELITIAN DAN PEMBAHASAN}

Deskripsi data responden akan dibahas mengenai jawaban kuesioner dari karakteristik responden berdasarkan jenis kelamin, fakultas dari responden, umur, asal daerah responden, alasan utama memilih fakultas, aktivitas responden selain di ruang kuliah, waktu aktivitas per hari dari responden, dan asal sekolah menengah atas (SMA).

Berdasarkan data, dapat diketahui bahwa mayoritas responden yaitu mahasiswa dengan jenis kelamin perempuan.

Tabel 1. Distribusi responden berdasarkan jenis kelamin (dalam \%)

\begin{tabular}{lcc}
\hline Jenis kelamin & $\begin{array}{c}\text { Jumlah } \\
\text { responden }\end{array}$ & $\begin{array}{c}\text { Jumlah } \\
\text { responden (\%) }\end{array}$ \\
\hline Laki - laki & 26 & 24,76 \\
Perempuan & 79 & 75,24 \\
\hline
\end{tabular}


Berdasarkan data distribusi responden, dapat diketahui bahwa mayoritas responden yaitu mahasiswa dari fakultas kedokteran.

Variabel kualitas pelayanan diteliti dalam penelitian yang dilakukan menggunakan lima belas indikator dimodifikasi dan disesuaikan berdasarkan klasifikasi jasa (Schmenner, 1986) diperoleh dari Parasuraman et al. (1988). Variabel kepuasan mahasiswa diteliti dalam penelitian yang dilakukan menggunakan tiga indikator dimodifikasi dan disesuaikan dari Helgesen and Nesset (2007); Hanaysha (2011). Variabel valensi word of mouth diteliti dalam penelitian yang dilakukan menggunakan tiga indikator dimodifikasi dan disesuaikan dari Walker (2001); Khraim (2011); Ekiz et al. (2008).

Tabel 2. Distribusi responden berdasarkan fakultas dari responden (dalam \%)

\begin{tabular}{lcc}
\hline \multicolumn{1}{c}{ Fakultas } & Jumlah responden & Jumlah responden (\%) \\
\hline Fakultas Keguruan \& Ilmu Pendidikan & $\mathbf{4}$ & $\mathbf{3 , 8 1}$ \\
Fakultas Ekonomi & 9 & 8,57 \\
Fakultas Hukum & 12 & 11,43 \\
Fakultas Psikologi & 5 & 4,76 \\
Fakultas Teknik & 4 & 3,81 \\
Fakultas Pertanian dan Peternakan & 13 & 12,38 \\
Fakultas Kedokteran & 0 & 0 \\
Fakultas Ilmu Kesehatan & 33 & 31,43 \\
\hline
\end{tabular}

Proses analisis data penelitian menggunakan Structural Equation Model (SEM) dengan sampel sebanyak 105, sehingga teknik estimasinya digunakan maximum likelihood estimation. Model dilakukan estimasi dengan menggunakan Lisrel (Liniear Structural RELationships) 8.50. Proses dalam melakukan analisis data dengan teknik Structural Equation Model (SEM), estimasi dilakukan secara bertahap yaitu melakukan teknik Confirmatory Factor Analysis dan Full Structural Equation Model.

Hasil analisis data telah dilakukan dengan menggunakan Lisrel (Liniear Structural REL ationships) 8.50 yang menunjukkan nilai untuk digunakan dalam pengujian hipotesis penelitian. Pengujian hipotesis penelitian akan dilakukan dengan syarat taraf signifikansi sebesar 0,05 atau $5 \%$ pada nilai-t sebesar $\pm 1,96$. Adapun nilai $R^{2}$ berfungsi untuk menunjukkan seberapa jauh masing - masing variabel bebas mampu menjelaskan variabel terikat. Penjelasan selanjutnya sebagai berikut: 1) Hubungan pengaruh antara komponen kualitas pelayanan (SERVQUAL) pada komponen kepuasan mahasiswa (SATISFAC) memiliki nilai $\mathrm{R}^{2}$ adalah 0,61 . Nilai $\mathrm{R}^{2}$ dapat diartikan bahwa $61 \%$ varian dalam pembentukan kepuasan maha- siswa dapat dijelaskan dengan baik oleh satu variabel komponen yaitu kualitas pelayanan. Sedangkan sisanya sebesar 39\% dijelaskan oleh faktor lainnya. 2) Hubungan pengaruh antara komponen kepuasan mahasiswa dan komponen kualitas pelayanan terhadap komponen valensi word of mouth memiliki nilai $\mathrm{R}^{2}$ adalah 0,46 . Nilai $\mathrm{R}^{2}$ dapat diartikan bahwa $46 \%$ varian dalam pembentukan valensi word of mouth dapat dijelaskan dengan baik oleh dua variabel komponen yaitu kepuasan mahasiswa dan kualitas pelayanan. Sedangkan sisanya sebesar 54\% dijelaskan oleh faktor lainnya.

Hipotesis 1 pada penelitian menjelaskan pernyataan bahwa "kualitas pelayanan berpengaruh positif terhadap kepuasan mahasiswa”. Hasil analisis data berdasarkan nilai CR (critical ratio) adalah 6,740 dan nilai P adalah 0,0000. Nilai yang mencapai syarat tersebut menunjukkan bahwa kualitas pelayanan berpengaruh positif dan signifikan terhadap kepuasan mahasiswa, sehingga hipotesis 1 dapat diterima.

Hipotesis 2 pada penelitian menjelaskan pernyataan bahwa "kualitas pelayanan berpengaruh positif terhadap valensi word of mouth". Hasil analisis data berdasarkan nilai CR (critical ratio) adalah 1,830 dan nilai $P$ adalah 0,0000 . Nilai yang 
tidak mencapai syarat tersebut menunjukkan bahwa kualitas pelayanan berpengaruh positif tetapi tidak signifikan terhadap valensi word of mouth, sehingga hipotesis 2 dapat ditolak.

Hipotesis 3 pada penelitian menjelaskan pernyataan bahwa "kepuasan mahasiswa berpengaruh positif terhadap valensi word of mouth". Hasil analisis data berdasarkan nilai CR (critical ratio) adalah 2,100 dan nilai P adalah 0,0000. Nilai yang mencapai syarat tersebut menunjukkan bahwa kepuasan mahasiswa berpengaruh positif dan signifikan terhadap valensi word of mouth, sehingga hipotesis 3 dapat diterima.

Hasil pengujian hipotesis 1 menyatakan bahwa kualitas pelayanan berpengaruh positif terhadap kepuasan mahasiswa $(\mathrm{CR}=6,74 ; \mathrm{P}=$ 0,000). Hipotesis penelitian 1 dapat diterima, sehingga dapat mendukung hasil penelitian yang dijelaskan oleh Natalisa (2007), Ahmed et al. (2010), Hanaysha (2011), Sukwadi et al. (2011). Selain itu, kualitas pelayanan secara signifikan berpengaruh terhadap kepuasan mahasiswa.

Hasil pengujian hipotesis 2 menyatakan bahwa kualitas pelayanan berpengaruh positif terhadap valensi word of mouth. Hipotesis penelitian 2 $(\mathrm{CR}=1,83 ; \mathrm{P}=0,000)$ dapat ditolak dengan mempertimbangkan nilai CR yang kurang dari 1,96 pada signifikansi sebesar 0,05 atau $5 \%$ dan nilai $P$ adalah $\leq 0,05$. Hasil penelitian tidak mendukung penelitian yang dilakukan oleh Praswati (2009) dan Sa' adah (2011). Hal tersebut dapat terjadi dikarenakan Praswati (2009) dan Sa'adah (2011) melakukan penelitian pada klasifikasi jasa dan karakteristik waktu kunjungan pelanggan yang berbeda. Perbedaan klasifikasi jasa akan mempengaruhi karakter proses penyampaian jasa (Schmenner, 1986). Kualitas pelayanan pada sektor jasa pendidikan berpengaruh positif secara tidak langsung terhadap valensi word of mouth melalui kepuasan mahasiswa. Hubungan secara tidak langsung tersebut dapat mendukung penelitian Sudiasa (2011) yang menggunakan obyek penelitian pada sektor jasa asuransi dengan menyatakan bahwa kualitas pelayanan bepengaruh positif dan signifikan secara tidak langsung terhadap word of mouthmelalui kepuasan pelanggan.
Hasil pengujian hipotesis 3 menyatakan bahwa kepuasan mahasiswa berpengaruh positif terhadap valensi word of mouth $(\mathrm{CR}=2,100 ; \mathrm{P}=$ 0,000). Hipotesis penelitian 3 dapat diterima, sehingga dapat mendukung hasil penelitian yang dijelaskan oleh Matos and Rossi (2008) bahwa kepuasan pelanggan berpengaruh positif dan signifikan terhadap valensi word of mouth. Hasil analisis tersebut dapat menjelaskan bahwa kepuasan mahasiswa berpengaruh positif dan signifikan secara langsung terhadap terjadinya valensi word of mouth pada sektor jasa pendidikan. Selain itu, kepuasan mahasiswa secara signifikan berpengaruh terhadap valensi word of mouth.

\section{SIMPULAN}

Berdasarkan hasil penelitian dapat disimpulkan bahwa dinamika proses perilaku konsumen pendidikan tinggi pada mahasiswa Universitas Muhammadiyah Malang dapat dijelaskan secara umum melalui pengaruh hubungan antara variabel kualitas pelayanan, kepuasan mahasiswa, dan valensi word of mouth. Hubungan antara variabel penelitian dapat dinyatakan sebagai berikut:

Kualitas pelayanan berpengaruh positif dan signifikan terhadap kepuasan mahasiswa. Hal dalam penelitian menunjukkan bahwa kualitas pelayanan administrasi yang semakin baik dapat meningkatkan kepuasan mahasiswa terhadap Universitas Muhammadiyah Malang. Sebaliknya kualitas pelayanan administrasi yang tidak baik dapat mengurangi kepuasan mahasiswa, sehingga berkontribusi pada persepsi mahasiswa di Universitas Muhammadiyah Malang. Penelitian menunjukkan bahwa mayoritas mahasiswa menganggap kualitas pelayanan administrasi di Universitas Muhammadiyah Malang sudah cukup baik dengan harapan semakin lebih baik lagi secara berkelanjutan.

Kualitas pelayanan berpengaruh positif tetapi tidak signifikan terhadap valensi word of mouth. Kualitas pelayanan yang dipersepsikan oleh responden (mahasiswa) dengan kriteria cukup baik ternyata masih belum bisa secara langsung mempengaruhi valensi word of mouth, sehingga harus melalui kepuasan mahasiswa untuk menghasilkan 
valensi word of mouthyang berguna untuk kegiatan promosi perguruan tinggi swasta. Namun, kualitas pelayanan dengan kriteria baik atau sangat baik dapat dimungkinkan secara langsung mempengaruhi valensi word of mouth.

Kepuasan mahasiswa berpengaruh positif dan signifikan terhadap valensi word of mouth. Penelitian menunjukkan bahwa kepuasan mahasiswa yang cukup puas ternyata secara langsung mempengaruhi tindakan mahasiswa untuk melakukan valensi word of mouth. Hal dalam penelitian menjelaskan semakin tinggi tingkat kepuasan mahasiswa, maka semakin meningkatkan intensitas melakukan valensi word of mouthyang dapat berkontribusi pada promosi perguruan tinggi swasta.

Hasil penting setelah analisis data dalam penelitian diidentifikasi bahwa kualitas pelayanan berpengaruh positif secara tidak langsung terhadap valensi word of mouth melalui kepuasan mahasiswa pada sektor jasa perguruan tinggi (mass service). Sedangkan kepuasan mahasiswa berpengaruh positif dan signifikan secara langsung terhadap terjadinya valensi word of mouth.

\section{DAFTAR PUSTAKA}

Abiawan, Hwan Nico. 2011. Pengaruh kualitas pelayanan terhadap word of mouth konsumen rumah makan khas sunda balibu (Abstrak). Tugas Akhir Ilmu Komunikasi. Universitas Pelita Harapan

Adisaputro, Gunawan. 2010. Manajemen pemasaran: analisis untuk perencanaan strategi pemasaran. UPP STIM YKPN. Yogyakarta.

Ahmed, Ishfaq, Muhammad Musarrat Nawaz, Zulfqar Ahmad, Zafar Ahmad, Muhammad Zeeshan Shaukat, Ahmad Usman, Wasim-ulRehman and Naveed Ahmed. 2010. Does service quality affect students' performance? Evidence from institutes of higher learning. African Journal of Business Management 4 (12): 2527 - 2533

Alex. 2006. Service marketing and non profit marketing. Diakses dari http:// www.alex@udel.edu
Alexandru, Bajenaru. 2010. The art and science of word of mouth and electronic word of mouth. Fascicle of Management and Technological Engineering 9 (19): 7 - 16

Alma, Buchari. 2008. Manajemen corporate dan strategi pemasaran jasa pendidikan. Alfabeta. Bandung

Anderson, Eugene W.. 1998. Customer satisfaction and word of mouth. Journal of Service Research 1(1): 5 - 17

Anonymous. 2007. Word of mouth marketing. Diakses dari http:// www.womma.com/

Asnawi, Nur dan Masyhuri. 2009. Metodologi riset manajemen pemasaran. UIN Press. Malang. pp. 297

Barata, Atep Adya. 2006. Dasar - dasar pelayanan prima. Gramedia. Jakarta.

Bates, Keith W. 2005. An introduction to word of mouth marketing. The Illinois Technology Association. United States of America. p. $1-35$

Brady, Michael K. and J. Joseph Cronin. 2001. Some new thoughts on conceptualizing perceived service quality:A hierarchical approach. The Journal of Marketing 65 (3): $34-49$

Bruce, Grady and Rachel Edgington. 2008. Factors influencing word-of-mouth recommendations by MBA Students: An examination of school quality, educational outcomes, and value of the MBA. Journal of Marketing for Higher Education 18(1): 79 - 101

Davidow, Moshe. 2003. Have you heard the word?The effect of word of mouth on perceived justice, satisfaction, and repurchase intentions following complaint handling. Journal of consumer satisfaction, dissatisfaction, and complaining behavior 16: 67 - 80

Ekiz, Erdogan H., Huseyin Arasli, Guita Farivarsadri and Ali Bavik. 2008. Measuring organizational responses to the student complaints in the perceived justice framework: Some evidence from northern cyprus universities. Educational Research and Reviews 3(7): 246 - 256 
File, K.M., Cermak, D.S.P. and Prince, R.A.. 1994. Word of mouth effects in professional services buyer behavior. The Service Industries J ournal 14(3): 301 - 314

Gremier, Dwayne D. and Stephen W Brown. 1997. Service loyalty: its nature, importance, and implications. University of Karlstad. Sweden. p. 171 - 181

Hanaysha, Jalal R. M. 2011. Service quality and satisfaction among postgraduate students at universiti utara malaysia. Thesis Master of Science Universiti Utara Malaysia.

Hanaysha, Jalal R. M., Haim Hilman Abdullah and Ari Warokka. 2011. Service quality and students' satisfaction at higher learning institutions: the competing dimensions of Malaysian Universities' competitiveness. Journal of Southeast Asian Research. 1 10

Harjadi, Didik dan Dewi Fatmasari. 2008. Word of mouth communication sebagai alternatif kreatif dalam komunikasi pemasaran. Equilibrium 8 (4): 72 - 78

Helgesen, Øyvind and Erik Nesset. 2007. Images, satisfaction and antecedents: Drivers of student loyalty? A case study of a Norwegian University College. Corporate Reputation Review 10 (1): 38 - 59

Indrajit, Richardus Eko dan Richardus Djokopranoto. 2004. Manajemen perguruan tinggi modern. Diakses dari http:// www.google.co.id/

Jasfar, Farida. 2005. Manajemen jasa: pendekatan terpadu. Ghalia Indonesia. Bogor. pp. 252

Khodayari, Faranak and Behnaz Khodayari. 2011. Service quality in higher education case study: measuring service quality of Islamic Azad University, Firoozkooh branch. Interdisciplinary J ournal of Research in Business 1 (9): 38 - 46

Khraim, Hamza Salim. 2011. The willingness to generate positive word of mouth marketing: The case of students in private universities in Jordan. Pertanika J. Soc. Sci. and Hum. 19 (2): 273 - 289
Kotler, P. and Keller, K. L. 2006. Marketing management, 12th ed. Prentice Hall International, Inc. New Jersey.

Marimuthu, Malliga dan Ishak Ismail. 2012. Service Quality in Higher Education: Com paring the Perceptions of Stakeholders. Ninth AIMS International Conference on Management: 515 - 523

Matos, Celso Augusto de and Carlos Alberto Vargas Rossi. 2008. Word-of-mouth communications in marketing: a meta-analytic review of the antecedents and moderators. Journal of The Academic Marketing Science 36 : $578-596$

Natalisa, Diah. 2007. Survey kepuasan pelanggan program studi magister manajemen universitas sriwijaya. J urnal Manajemen dan Bisnis Sriwijaya 5 (9): 83 $-98$

Parasuraman, A., Zeithaml, and Berry. 1988. Servqual: a multiple-item scale for measuring consumer perceptions of service quality. J ournal of Retailing Spring 64: 12 $-40$

Sa'adah, Jahizatus. 2011. Pengaruh servicequality terhadap satisfaction, trust, dan loyalitas dalammembentuk word of mouth (Studi pada resto di Kota Tuban). Diakses dari http://www.google.co.id/

Sawaji, J., Djabir Hamzah dan Idrus Taba. 2010. Pengambilan keputusan mahasiswa dalam memilih perguruan tinggi swasta di Sulawesi Selatan. Diakses dari http:// www.google.co.id/

Schmenner, R.W. 1986. How can service businesses survive and prosper. Sloan Management Review 27 (3): 21 - 32

Seth, Nitin, S.G. Deshmukh, and Prem Vrat. 2005. Service quality models: a review. International J ournal of Quality and Reliability Management 22 (9): 913 - 949

Solimun. 2004. Structural equation modeling (SEM), aplikasi software Amos. FMIPA dan Program Pascasarjana Universitas Brawijaya. Malang 
Storey, Chris and Christoper J. Easingwood. 1998. The augmented service offering a conceptualization and study of its impact on new service success (Abstract). Journal of Product Innovation Management 15

Sudiasa, I Ketut. 2011. Pengaruh kualitas pelayanan terhadap word of mouth melalui kepuasan klaimen pada PT Jasa Raharja (PERSERO) Cabang Nusa Tenggara Barat (Abstrak). Tesis Manajemen. Universitas udayana

Sukwadi, Ronald, Ching-Chow Yang, and Fan Liu. 2011. Towards an identification and classification of service quality attributes in higher education. International Journal of e-Education, e-Business, e-Management and e-Learning 1 (2): 163 - 168

Sylvana, Andi. 2006. Pengaruh kualitas pelayanan dan kepuasan mahasiswa terhadap intensi meregistrasi ulang mahasiswa. Jurnal Organisasi dan Manajemen 2 (1): 60 - 78

Taylor, Steven A. 1996. Consumer satisfaction with marketing education: extending services theory to academic practice. Journal of Consumer Satisfaction, Dissatisfaction and Complaining Behavior 9: 207 220
Teerawut, Techachaicherdchoo. 2011. Undergraduate student's satisfaction toward the new education system in Thailand. International journal of social sciences and humanity studies 3 (2): 443 - 445

Tjiptono, F., Chandra, G., dan Dedi Adriana. 2008. Pemasaran strategik. Penerbit Andi. Yogyakarta.

Walker, L. Jean Harrison. 2001. The measurement of word-of-mouth communication and an investigation of service quality and customer commitment as potential antecedents. Journal of service research 4 (1): $60-75$

Wantara, Pribanus. 2009. Pengaruh citra, reputasi, dan kualitas pelayanan terhadap kepuasan dan loyalitas mahasiswa PTS di Jawa Timur (studi pada STIE dengan program studi terakreditasi). Jurnal Aplikasi Manajemen 7: 326 - 334

Wijanto, Setyo Hari. 2008. Structural equation modeling dengan lisrel 8.8. Graha ilmu. Yogyakarta.

Wijaya, David. 2008. Pemasaran jasa pendidikan sebagai upaya untuk meningkatkan daya saing sekolah. Jurnal Pendidikan Penabur 11: 42 - 56

Williams, Megan. 2007. Word of mouth: a definition of communication. Elmhurst College 